\title{
Følelser i sundhed og sygdom - genbesøgt
}

\section{Mai-Britt Guldin \& Ann Dorrit Guassora}

Aarhus Universitetshospital og Aarhus Universitet

m.guldin@ph.au.dk

Københavns Universitet

anngu@sund.ku.dk

Guldin, Mai-Britt \& Guassora, Ann Dorrit (2016). Følelser i sundhed og sygdom genbesøgt. Tidsskrift for Forskning i Sygdom og Samfund, nr. 24, 5-15

Er mennesket grundlæggende styret af fornuft eller følelse? Det ældgamle spørgsmål: Er følelser konstruktive størrelser eller uhensigtsmæssige forstyrrelser i et menneskeliv? Hvordan beriger følelserne vores liv, og spiller de en rolle i vores sundhed og sygdom? . I Jane Austens roman Fornuft og følelse, som finder sted i den engelske overklasse i forrige århundrede, udspilles et drama om betydningen af fornuft og følelse i tilgangen til livet og kærligheden. Dilemmaet mellem fornuft eller følelse illustreres ved at portrættere storesøsteren Elinor Dashwood, som lader sig lede af fornuften og lillesøsteren Marianne Dashwood, som er impulsiv og i sine følelsers vold. I lyset af dette dilemma udspindes en kærlighedshistorie om kvindernes tilgang til livet og deres relationer, og det giver brændstof til handlingen, at netop følelserne enten får overtaget eller bliver behersket og undertrykt.

Det grundlæggende spørgsmål om fornuft og følelse har dannet baggrund for dette temanummer, og en række professionelle og forskere med forskellige disciplinære baggrunde belyser med deres bidrag en række dimensioner og aspekter af emotioner eller her benævnt følelser; deres rolle i nutiden og i forhold til individ, relationer, sygdom og samfund. 


\section{Følelser og sundhed}

Eksisterende viden om følelser er kompleks, og forskningen i menneskets følelsesliv har de sidste årtier ledt til store begrebsmæssige ændringer i den grundlæggende forståelse af følelser, deres fænomenologi, struktur og funktion i menneskelivet gennem tiden. Følelser forstås som en sansning eller arousal i personens affektive tilstand og en fænomenologisk og psykologisk proces med at tolke sansningen (Den store danske encyclopædi). Følelser blev i mange år defineret på et deskriptivt niveau på baggrund af deres fænomenologi. For eksempel har forskningen forsøgt at kortlægge følelsers varighed, intensitet, dybde, subjektive udtryk, polaritet og genstandsrettethed. Forståelsen af følelser er i dag, at de har både biologiske, kulturelle og psykologiske komponenter og både kan begribes artsmæssigt evolutionært (fylogenetisk) og individuelt partikulært (ontogenetisk). I et evolutionært perspektiv mener man, at følelser er opstået, fordi de hjælper os med at aktivere og koordinere forskelligartede respons-systemer, som sikrer en adækvat respons på udfordringer og muligheder (Gross, 1999). Tag angst for eksempel. Når vi oplever angst, påvirkes det autonome nervesystem, og det endokrine responssystem, vores kognition indsnævres, sanserne skærpes, det kardiovaskulære system er klar til at øge oxygenforbruget til det muskulære system og musklerne spændes og er forberedte på at flygte fra fare. Dette er en meget adaptiv respons, som har været med til at sikre artens overlevelse. Men den emotionelle respons kan også være maladaptiv. Dette sker, når angst udvikler sig uhensigtsmæssigt ofte, og selvom der ikke er reel fare på færde, men responsen er blevet overaktiv eller udløses i situationer, som er fejlfortolkede, og hvor der egentlig ikke er fare. Nu er responsen blevet maladaptiv og kan påvirke livet negativt eller endda invalidere individet i dets hverdag. Her kommer begrebet omkring følelsernes påvirkning af vores sundhed ind på scenen.

Forskningen om følelser er i dag især koncentreret om forholdet mellem følelser og sundhed og sygdom. Følelser er blevet sat i forbindelse med sundhedsadfærd og helbredsproblemer, og et af de mest udforskede og centrale eksempler herpå er, hvorvidt positive følelser påvirker helbredet positivt. En karakteristisk tanke har været, at positive følelser og en positiv holdning påvirker immunforsvaret positivt og dermed befordrer sundhed. Og i tråd hermed, at negative følelser, vrede, sorg og traumer kan påvirke personen fysiologisk og forårsage hjerte-kar sygdomme, kræft mv. (Salovey et al., 2000).

Sundhedspsykologien har som sin centrale forskningsgenstand samspillet mellem følelser og sundhedsadfærd samt sygdomsmønstre. I denne del af forsknin- 
gen undersøges hvilke sammenhænge, der er mellem følelser og stress, påvirkning af immunforsvar, personlighed og sundhedsadfærd, samt hvordan personen benytter copingprocesser til at håndtere sygdom og lidelse (Gross, 1998). Fx har det igennem mange år været et centralt forskningsspørgsmål om livsstilssygdomme, som hjerte-kar sygdomme, kræft og kroniske smerter, indbefatter psykologiske årsagsfaktorer, samt omvendt hvilke påvirkninger sygdommene har på det mentale helbred (psykosomatik og somatopsyke). Et eksempel her kunne være forekomsten af angst og depression hos kræftpatienter, og hvordan det påvirker sygdomsforløbet. I det hele taget beskæftiger sundhedspsykologien sig med at fremme og bevare fysisk og psykisk sundhed ved at øge viden om psykiske faktorers indflydelse på udviklingen og behandlingen af sygdomme.

\section{Følelser og tilknytningsteori}

Psykologisk set har forståelsen af individets følelsesliv også taget udgangspunkt i forskningen i hukommelse og indlærte tolkninger af kropslige sansninger og via neuropsykologien, som har bidraget med undersøgelser om, hvordan følelser kan forstås på et neuralt og biokemisk niveau. Neuropsykologien har bl.a. øget forståelsen af sammenhænge mellem neurokemi, affektive tilstande og patofysiologien i mentalt helbred (Damasio, 1999). En del af den forskning, der indenfor psykologien har været grundlæggende i forhold til følelser og følelsesmæssig sundhed, er begrebet om tilknytning. Med tilknytning menes menneskets grundlæggende tendens til at knytte betydningsfulde følelsesmæssige bånd til andre mennesker for at sikre tryghed, hjælp og større overlevelseschancer (Mikulincer \& Shaver, 2013). Da mennesket fødes hjælpeløst, er det afhængig af den tilknytning, der er til forældrene, og tilknytning er således en primær overlevelsesmekanisme (ibid). Tilknytningen har vist sig at have en central indflydelse på personlighedens udvikling, følelsesmæssig intelligens og evnen til at indgå i relationer, oparbejde indlevelsesevne og situa`tionsfornemmelse (ibid). Tilknytningsteorien har ikke direkte beskæftiget sig med tilknytningens rolle i sundhed og sygdom, men der er forskning, der peger på, at problemer med tilknytningsstil i de nærmeste relationer (usikker tilknytningsstil) er associeret med en lang række psykopatologiske lidelser og problemer i det mentale helbred, fx angst, depression, personlighedsforstyrrelser, spiseforstyrrelser, alkoholmisbrug mv. (ibid). Da forskningen indenfor disse emner er forholdsvis ny, er der dog fortsat tvivl om, hvad der er hønen og ægget i de sammenhænge, man finder forskningsmæssigt. Er det usikker til- 
knytning, der forårsager problematisk følelsesforvaltning under sygdom, eller er det sygdommen, der påvirker følelsesforvaltningen og forårsager problemer med tilknytning. Eller sandsynligvis påvirker processerne hinanden. Forskningen i sundhedsadfærd og sygdomsmønstre har vist sig at være påvirket af den følelsesmæssige støtte, individet forstår at oparbejde, og dette afhænger bl.a. af den tilknytningsstil, personen har indlært, personens følelsesmæssige intelligens og sociale kompetencer (ibid).

\section{Følelsesregulering}

Der bliver i stadig højere grad fokuseret på hvordan følelsesregulering kan påvirke psykosomatiske og somatopsykiske reaktioner på sygdom og sundhedsadfærd. Forskningen om følelsesregulering beskæftiger sig med, hvor stor en rolle det spiller i forhold til resiliens og sundhed, at man kan regulere sine egne følelsesmæssige reaktioner (DeSteno et al., 2013). Følelsesregulering er en normal del af menneskets hverdag og defineres som neurale, kognitive og adfærdsmæssige processer, der påvirker den indre vedligeholdelse og op- og nedregulering af følelsesmæssige tilstande (Izard et al., 2011). I forskningen om følelsesregulering har det været et centralt spørgsmål, om undertrykkelse eller udtrykkelse af emotioner fremmer eller hæmmer udviklingen af sygdom. En populær myte har eksempelvis været, at undertrykkelsen af vrede var associeret med mavesår, forhøjet blodtryk og hjertesygdom, eller at undertrykkelsen af negative følelser som sorg kunne accelerere udviklingen af kræft (Gross, 1998). Studier om følelsesmæssig dysregulering og mentalt helbred er blevet meget populære, især følelsers rolle i forbindelse med psykopatologi (Salovey et al., 2000). Manglende følelsesregulering har i undersøgelser vist sig at spille en rolle i forbindelse med personlighedsforstyrrelser, depression, angst, misbrugsadfærd, spiseforstyrrelser, og der er påvist sammenhæng mellem funktionelle lidelser og problemer med at tolke følelsesmæssige tilstande samt kropslige sensationer (Berking \& Wupperman, 2012). Manglende følelsesregulering har også været sat i forbindelse med usikker tilknytningsstil, da personen, via den relationelle interaktion mellem barn og primær voksen i starten af livet, ikke har lært at have tillid til den sociale støtte og regulere følelsesmæssige tilstande (Mikulincer \& Shaver, 2013). 


\section{Social organisering, intersubjektivitet og følelser}

Betydningen af følelser i sociale relationer og strukturer er også behandlet i sociologien (fx Hochshild, 1983). Hochshild viser, hvordan det kræves af os i bl.a. vores arbejdsliv, at vi præsenterer os med en professionel følelsesmæssig indstilling og regulerer egne følelser. At passe det følelsesmæssige indtryk ind i arbejdet gøres med "følelsesarbejde". Følelsesarbejde er en stor del af det "at arbejde med mennesker" (Hochshild, 1983) og således også det at være sundhedsprofessionel. Følelsesmæssige krav til professionelt arbejde i sundhedsvæsenet er f.eks. at vise empati (Obling, 2012), men der findes også anbefalinger til sundhedsprofessionelle inspireret af Carl Rogers (1951) om at vise ubetinget positiv og ikke-dømmende indstilling til patienterne. Tankegangen har bl.a. inspireret den mest anbefalede strategi til at motivere patienter for ændring af sundhedsvaner, Motiverende Interviewteknik, som anbefaler, at den professionelle skal være "non-judgemental" (Rollnick et al. 2008).

I antropologien var følelser i en periode et stort tema som en del af psykologisk antropologi (Lutz 1988; Lutz \& White 1986; Rosaldo 1984; Shweder 1994). Men vægten på følelser ændrede sig til fordel for "subjektivitet," "embodiment," "personhood" og "erfaring" og gjorde studier af følelser til et aspekt af flere indbyrdes sammenhængende forhold snarere end et specifikt emne eller særligt interesseområde (Beatty 2013). Det er her, forskere som Byron Good, Arthur Kleinman, Thomas Cordas og Michael Jackson kommer på banen (Biehl, Good \& Kleinman, 2007; Csordas, 2002; Jackson, 1989). I kølvandet på disse er antropologien de senere år igen begyndt at studere følelser som et fokusområde og som omdrejningspunkt for centrale mellemmenneskelige handlinger, en udvikling som bl.a. opstår via interessen for kognition og følelsers rolle og samspil med kognition. Disse studier har overordnet afsæt $i$ et analytisk fokus på verden som globaliseret og kompleks, men med feltarbejdet som metodemuligheden, der rummer det almene, hverdagslige interaktionsniveau. I den sammenhæng diskuteres, hvad følelser er, og især hvordan man nærmer sig følelser empirisk og analytisk (Beatty 2013). I både generel antropologi og medicinsk antropologi er empati f.eks. blevet et ofte aktuelt tema, metodologisk som en del af feltarbejdets kilder til viden og som emne for etnografiske studier af intersubjektive processer (Hollan \& Throop 2011). Ofte diskuteres også 'political emotions' eller følelsers politiske økonomi bl.a. i forbindelse med medikalisering af følelser. Generelt synes den del af antropologien, som har fokus på følelser at være i fortsat udvikling, metodisk om hvordan følelser kan 
studeres og skrives om, og videnskabsteoretisk om hvordan følelser skal forstås gennem at genopdage følelsers partikularitet (Beatty 2013).

\section{Artiklerne i dette nummer}

Artiklerne i dette temanummer fokuserer på følelsesregulering, på tilknytningens betydning for følelsesforvaltning, på den sociale organisering omkring følelser og på kropslighedens betydning for forståelsen af egne og andres følelser. Følelser betragtes som funktionelle, men de er ikke altid hjælpsomme, og derfor kan der være behov for at regulere dem for at livskvaliteten øges. James Gross' procesmodel om følelsesregulering har været meget indflydelsesrig og danner bl.a. baggrund for følelsesregulerings terapi. Emnet omkring tilknytning og følelsesforvaltning præsenteres, samt hvordan følelser reguleres eller ikke reguleres i nære relationer, og hvad dette betyder for individuel trivsel og social støtte. Social organisering og følelsernes plads i denne organisering analyseres, og det vises, hvordan følelser håndteres i sociale strukturer. Interaktion indenfor institutionelle rammer indeholder sociale regler for, hvordan og hvor følelser kan præsenteres. Således kan organiseringen af samhandling i institutioner anvise mere eller mindre faste pladser for følelser. Det er også tilfældet for fysiske rum, som i nogle tilfælde er bygget til at afspejle de sociale relationer og det møde mellem mennesker, som bygningen er ramme om. Nummeret afsluttes med at behandle kroppen, som spiller en vigtig rolle i kommunikationen om følelser. I en fænomenologisk forståelse betyder kropsligheden, at man er i stand til at erfare den anden direkte og uden en skarp skelnen mellem psykologiske og adfærdsmæssige aspekter og således også forstå følelser.

Med artiklen 'Angst og depression: Følelsesregulering i psykoterapi' præsenterer Mia O'Toole og Esben Hougaard den nyeste forskning om begrebet følelsesregulering. Følelsesregulering er indenfor de seneste 20 år blevet et selvstændigt forskningsfelt og defineres i artiklen som en persons automatiske og strategiske regulering af en følelses udvikling i personen. Følelser betragtes som funktionelle, men de er ikke altid hjælpsomme, og derfor kan der være behov for at regulere følelserne for, at livskvaliteten øges. O'Toole og Hougaard tager udgangspunkt i James Gross' indflydelsesrige procesmodel om følelsesregulering. Læseren føres gennem følelsesreguleringsteorien og behændigt forklares, hvordan følelser bygger på stimuli inden i personen, som vurderes og underlægges en række processer, som til slut fører til en følelsesmæssig respons. Undervejs gives forklaringer 
på, hvordan følelsesmodulering og uhensigtsmæssig følelsesregulering kan skabe problemer i personens følelsesmæssige udtryk og føre til psykisk lidelse, relationelle problemer og forringet livskvalitet. Til eksemplificering benyttes angst og depression, som begge er karakteriseret ved øget følelsesmæssig reaktivitet, hvor følelsesudtrykket bliver dysreguleret, og der er behov for metakognitive strategier, som kan bidrage til mere regulering. Forfatterne beriger os med eksempler på terapiformer, som fokuserer på måder at forbedre følelsesreguleringen, men forklarer også, at erfaringen med følelsesreguleringsterapi er begrænset, og det er endnu uvist, hvorvidt det er gavnligt for andre klientgrupper.

Lauridsen og kolleger forklarer os, hvordan følelser og konflikter i parforholdet kan forstås indenfor rammerne af tilknytningsteorien. De benytter således tilknytningsteori som en ramme for at beskrive og forstå, hvordan voksne håndterer følelser og konflikter i parforholdet, og hvordan negative emotioner påvirker nære relationer. Tilknytningsteorien går tilbage til 1950'erne, og forfatterne præsenterer Bowlby som ophavsmand til teorien, som omhandler de tidlige omsorgserfaringer, som barnet oplever i mor-barn forholdet, og hvordan de udvikles til forventninger, kaldet indre arbejdsmodeller, til fremtidige relationer fx parforholdet. Artiklen er et systematisk litteraturstudie af nyere forskning om sammenhængen $\mathrm{ml}$ voksnes tilknytningsmønstre og den måde, konflikter håndteres i parforholdet. Gennemgangen afslører ti studier, der inddeler voksne i trygt og utrygt tilknyttede personer, og hvor de utrygt tilknyttede personer udviser mere negativ adfærd som kritik og afvisning, mens trygt tilknyttede i højere grad formår positiv adfærd som empati og åbenhed. I en konfliktsituation vil en trygt tilknyttet person have tendens til at reagere med sensitivitet og respondere på partneres behov, mens de utrygt tilknyttet person er mindre bevidst om partnerens følelser og intentioner og derfor udviser mindre omsorg. Forfatterne går videre til at diskutere, hvorledes studierne om konfliktadfærd også byder på information til sundhedsprofessionelle om, hvorfor nogle patienter og pårørende bliver fanget i uhensigtsmæssig konfliktadfærd. Også i denne artikel diskuteres manglende evne til følelsesregulering som vigtig for udviklingen af konfliktadfærd, og hvis personen ikke har lært strategier til at berolige sig selv i de tidlige relationer, så kan dette oparbejdes via Emotions Fokuseret Terapi, som har fokus på udviklingen af hensigtsmæssige strategier til at regulere uro og følelser.

Christel Tarber viser i sin artikel, hvordan rammer i den traditionelle konsultation i almen praksis og anbefalinger til håndtering af patienter med medicinsk uforklarede symptomer (MUS) udmøntes i en konsultation hos en praktiserende læge og de konflikter, der er mellem den professionelle ramme og patientens dags- 
orden. Analysen viser, hvordan lægen aktivt fokuserer på andre aspekter af det fortalte end det følelsesmæssige gennem 'ancillary questions'. Patienten vender undervejs i konsultationen tilbage til lidelsesaspektet, mens lægen på sin side arbejder på at opnå enighed om en plan for videre undersøgelser og følger således den institutionelle ramme for interaktionen i en konsultation. Logikken i den almenmedicinske konsultation betyder, at MUS-patientens følelsesmæssige problemer i dette tilfælde ikke bliver mødt, og de to dagsordner bliver ved med at krydse hinanden uden at mødes. Patienten fortæller videre om sin kamp for at være en god patient og lade sig indlægge og undersøge på trods af sin angst for sundhedsvæsenet. Også dette er et problem for en patient med MUS, som ikke er sikker på at opnå en legitim status som syg og dermed en legitim sygerolle.

I artiklen '"Dette er ikke et hospital": Rum, følelser og professionel ekspertise i dansk kræftrehabilitering' viser Anne Obling, hvordan nyt byggeri til rehabilitering ikke kun har en anderledes profil end de traditionelle behandlingsinstitutioner, men også indbefatter en række moralske antagelser om menneskelige behov og følelser samt en form for adfærdsinformation, som både udstikker en ramme for arbejdets organisering samt stiller nye krav til det at være sundhedsprofessionel medarbejder. Artiklen bygger på ideen om, at der er en signifikant forbindelse mellem rum og følelse og professionel ekspertise/funktion, og at specifikke bygninger har indbygget normer og standarder for den moralske regulering af den sociale adfærd. Analysen er inspireret af Norbert Elias'analyse af det franske hofsamfund, som udgjorde et arnested i historien for en mere systematisk og vedholdende forstillelse af følelser og for at knytte følelsesregulering til organisationen. Analysen viser bl.a., hvordan den tilsyneladende mere fri, hjemlige adfærd i en kræftrehabiliteringsenhed - herunder spontane følelsesudtryk, i praksis er guidet af usagte, temmelig rigide regler for, hvordan uformel hjertelighed fremstilles både verbalt og i brug af et specifikt kropssprog. Atmosfæren i det åbne atrium midt i bygningen signalerer en hjemlighed, som passer dårligt sammen med professionelle krav til distance, som fx sygeplejerskerne i enheden er trænet i, og derfor må den af bygningen foreskrevne ikke-institutionelle adfærd korrigeres gennem fx personalemøder om fælles standarder for professionelle relationer. Det kræver ekstra arbejde at korrigere for de sociale samværsformer, som huset lægger op til.

I deres artikel peger Annette Davidsen og Christina Fosgerau på kropslighedens betydning for etablering af forståelse af andres emotioner. Udgangspunktet er, at følelser ofte er i spil i samtaler mellem læger og patienter og har stor betydning for etableringen af forståelse. I artiklen præsenteres mentaliseringsteorien 
som en mulig forklaringsmodel. Mentalisering betyder at være opmærksom på, at sætte sig ind i og forstå mentale tilstande og processer hos en selv og andre. Mentaliseringen vedrører forskellige mentale processer som følelser, tanker, behov, ønsker, forestillinger, begær, tro, fantasier, drømme osv., foruden de mere patologiske som panik og dissociative tilstande, hallucinationer og vrangforestillinger. Mentaliseringsteorien præsenteres som en mulig forklaringsmodel til, hvordan forståelse af emotioner og følelser etableres. Davidsen og Fosgerau anbefaler teorien som et psykologisk velfunderet bud på forståelsen af andre menneskers følelser og emotioner og vurderer, at den er brugbar i alle former for læge-patient forhold, fordi mentalisering beskriver en almenmenneskelig kapacitet, der kan anvendes i alle typer konsultationer. De mener dog, at der i mentaliseringens teoretiske grundlag, theory of mind, ikke er redegjort tilstrækkeligt for den store del af etableringen af forståelse, som foregår uden at blive italesat og argumenterer for, at fænomenologi er et bedre teoretisk udgangspunkt. I en fænomenologisk forståelse betyder kropsligheden, at man er i stand til at erfare den anden direkte og uden en skarp skelnen mellem psykologiske og adfærdsmæssige aspekter. Forståelsen af den anden etableres ikke via en analogislutning eller teori, men gennem en direkte og irreducibel bevidsthedsform, hvori der også indgår en kropslig resonans, og hvorigennem den anden erfares direkte.

Kropslighedens betydning for lægens forståelse af patienten er også temaet i digtet "Rythm and blues - hinsides konsultationsprocessen" af Henrik Sångren. Han er afdelingslæge på afdelingen for Klinisk socialmedicin og rehabilitering, Hospitalsenhed Vest i Herning. Digtet fortæller hvordan lægen registrerer patientens største problem, som kniv eller medicin ikke kan afhjælpe. I den blå time, hvor lægen træder ud af sin formelle professionelle rolle, bliver der plads til de sansninger og umiddelbare forståelser af patientens pine, som ikke kan rummes $i$ de formelle medicinske rammer. Og måske er der netop brug for, at klinikeren kan rumme patientens lidelse sådan.

Tilbage til vores indledende spørgsmål om mennesket er styret af fornuft eller følelse, og om følelser er konstruktive eller uhensigtsmæssige og forstyrrende størrelser. Artiklerne i dette temanummer belyser især følelsernes rolle i den intrapersonelle og den interpersonelle sundhed og afslører en tentativ konklusion, om at følelsesregulering indebærer et delvis svar. Følelser har vigtige funktioner og bistår os i tolkningen af verden, men vi har brug for at kunne regulere dem for at bevare psykisk sundhed og for at kunne fungere socialt. Vi ved desværre ikke, hvad forfatteren Jane Austen ville mene om begrebet følelsesregulering. Det ville dog nok ikke kunne danne grobund for så store spændinger og forviklinger eller 
vittige beskrivelser af menneskets følelsesliv, som hun beriger os med i den 200 år gamle bog Fornuft og Følelse. Menneskelig følelsesregulering er dog nok en kompleksitet, som vil optage os mange år udi fremtiden. Og måske især følelsesreguleringens rolle i forhold til sundhed og sygdom.

God læselyst.

\section{Referencer}

Berking M \& Wupperman P. (2012) Emotion regulation and mental health: recent findings, current challenges, and future directions. Current Opinion in Psychiatry; 25 (2): 128-134.

Biehl, J., Good, B., \& Kleinman, A. (Eds.). (2007). Subjectivity: Ethnographic investigations. Berkeley: University of California Press.

Csordas, T. J. (2002). Body, meaning, healing. Basingstoke, UK: Palgrave Macmillan.

Damasio A. (1999). Descartes' fejltagelse. København: Hans Reitzels Forlag.

DeSteno D, Gross JJ, Kubzansky L. (2013). Affective science and health: the importance of emotion and emotion regulation. Health Psychology; 32 (5): 474-486.

Gross JJ. (1998). Antecedent- and reponse-focused emotion regulation: Divergent consequences for experience, expression, and Physiology. Journal of Personality and Social Psychology; 74 (1): 224-237.

Gross JJ. (1999). Emotion regulation: Past, present, future. Cognition and emotion; 13 (5): 551573.

Hochschild A. (1983) The managed heart: Commercialization of human feeling. London: University of California Press.

Hollan, D., \& Throop, C. J. (Eds.). (2011). The anthropology of empathy: Experiencing the lives of others in Pacific societies. New York, NY: Berghahn Books

Izard CE, Woodburn EM, Finlon KJ, Krauthamer-Ewing S, Grossman SR \& Sidenfeld A. (2011) Emotion knowledge, emotion utilization and emotion regulation. Emotion Review, 3 (44): 44-52.

Jackson, M. (1989). Paths towards a clearing: Radical empiricism and ethnographic enquiry. Bloomington: Indiana University Press.

Lutz, C. A. (1988). Unnatural emotions: Everyday sentiments on a micronesian atoll and their challenge to western theory. Chicago, IL: University of Chicago Press.

Lutz, C. A., \& White, G. (1986). The anthropology of emotions. Annual Review of Anthropology, 15, 405-436.

Mikulincer M \& Shaver PR. (2013). Attachment insecurities and disordered patterns of grief. I MS Stroebe, RO Hansson, Schut H \& Stroebe W (red.) Handbook of bereavement research and practice. Advances in theory and intervention. Washington, DC: American Psychological Association.

Obling A. (2012) Træning af kontrolleret empati i accelererede kræftbehandlingsforløb. Århus: Tidsskrift for Forskning i Sygdom og Samfund 17.

Rogers, C.R. (1951) Client-centered therapy: its current practice, implications and theory. Boston: Houghton Mifflin. 
Rollnick, S., Miller W.R., Butler, C.C. (2008) Motivational interviewing in health care: Helping patients change behavior. New York: Guilford Press.

Rosaldo, M. Z. (1984). Toward an anthropology of self and feeling. In R. A. Shweder \& R. A. Levine (Eds.), Culture theory: Essays on mind, self, and emotion (pp. 137-157). Cambridge, UK: Cambridge University Press

Salovey P, Rothman AJ, Detweiler JB \& Steward WT. (2000) Emotional states and physical health. American Psychologist; 55, 11: 110-121.

Shweder, R. A. (1994). "You're not sick, you're just in love": Emotion as an interpretive system. In P. Ekman \& R. J. Davidson (Eds.), The nature of emotion: Fundamental questions (pp. 32-44). New York, NY: Oxford University Press 